\title{
Effect of Some Fungicides on Foot and Root Rot of Lentil
}

\author{
M. A. Hoque ${ }^{1}$, I. Hamim ${ }^{1, *}$, M. R. Haque ${ }^{2}$, M.A. Ali ${ }^{1}$, M. Ashrafuzzaman ${ }^{1}$ \\ ${ }^{1}$ Department of Plant Pathology, Bangladesh Agricultural University, Mymensingh-2202, Bangladesh \\ ${ }^{2}$ Department of Biochemistry and Molecular Biology, Bangladesh Agricultural University, Mymensingh-2202, Bangladesh \\ *Corresponding Author: islam.hamim@gmail.com
}

Copyright (C) 2014 Horizon Research Publishing All rights reserved.

\begin{abstract}
An experiment was carried out to test the efficacy of four fungicides in controlling foot and root rot of lentil under field condition. The test fungicides were Rovral (0.2\%), Secure 600wg (0.2\%), Bavistin 70wp (0.2\%), Captan 50wp (0.2\%). BARI masur-1 has been used for this experiment. Tested fungicides significantly decreased incidence of foot and root rot of lentil and increased yield. Among the fungicides highest performance was found with Secure $600 \mathrm{wg}(0.2 \%)$ in controlling the incidence of foot and root rot.
\end{abstract}

Keywords Fungicides, Secure $600 \mathrm{wg}$, incidence, Foot and Root Rot

\section{Introduction}

Lentil occupies a unique position in the agriculture of Bangladesh. In Bangladesh pulses constitute an integral part of the daily diet as a direct source of protein for human beings [9]. Lentil (Lens culinaris) is one of the oldest and most familiar food legumes in Bangladesh. Lentil is the second most important pulse crop in terms of area $(154,000$ ha) and production $(116,000 \mathrm{t})$, but ranks the highest in consumer preference and total consumption [5]. Consumption of lentils with small grains provides a balanced diet. It is a cheap source of protein for human beings and also for animals in country [9]. Lentil is also important in crop diversification in the cropping systems of Bangladesh. As the price of animal protein is increasing day by day, the protein storage in the diet system of the people in the country can be met up through lentil. The yield of lentil in Bangladesh is lower (total production 124,000 metric tons; [5]) than that of Syria, Turkey, Canada, USA and Ethiopia. The low yield of lentil is associated with poor management practices, unavailability of quality seeds and specially lack of proper disease management. Diseases play important for yield reduction. Lentil is affected by a wide range of fungal diseases. Productivity of lentil is reduced by pathogens through infection and damage to leaves, stems, roots and pods. It also reduces marketability due to discoloration of the seeds. Lentil suffer from attack of a number seed borne diseases such as vascular wilt, collar rot, root rot, stem rot, rust, powdery mildew and downy mildew, which are caused by Fusarium oxysporum f.sp. lentis, Sclerotium rolfsii, Rhizoctonia solani, Uromycis fabae, Erysiphe polygoni and Peronospora lentis respectively [10 and 8]. Fusarium oxysporum and Sclerotium rolfsii are soil-borne pathogens commonly occurs in the tropics and sub-tropics regions of the world causing root and foot rot of many crops [3].

Foot rot (caused by Fusarium oxysporum and Sclerotium rolfsii) is considered as an important and destructive disease of pulses in almost all legume-growing countries of the world [1]. Foot and root rot of lentil caused by Fusarium oxysporum and Sclerotium rolfsii [6] are common in Bangladesh. In Bangladesh about 44\% lentil plants are infected by foot and root rot disease [1]. It causes seedling death at early stage resulting very poor plant stand which ultimately produces very low yield.

Despite of the many achievements in modern agriculture, chemical control still holds a strong performance in combating certain destructive plant diseases. Farmers use chemicals for controlling the diseases of crop plants in Bangladesh, but limited information on the efficacy of these chemicals exists in our country. No investigation has so far been conducted in the discipline of controlling foot and root rot of lentil by fungicides in Bangladesh. Considering the above facts the present study was undertaken to evaluate efficiency of the fungicides for controlling foot and root rot of lentil in field conditions of Bangladesh and asses foliar application of fungicides on lentil production.

\section{Materials and Methods}

\section{Lentil Seed Sowing and Application of Treatments}

The experiment was carried out at the field laboratory of the Pulse Research Station, Bangladesh Agricultural Research Institute (BARI), Joydebpur, Gazipur, in the period of October, 2011 to May, 2012. The lentil variety, BARI Masur-1, has been used in the study. The experimental plot was prepared mechanically in November, 2011. Weeds and other materials were removed. The soil was prepared into good tilth by six cross ploughings followed by ladderings. The soil of the field was leveled before seed sowing. 
Fertilizers such as Urea, TSP and MOP were applied @ 45, 85 and $35 \mathrm{~kg} / \mathrm{ha}$ and Cow dung @ 5 ton/ha during the time of final land preparation [4]. The experiment was conducted in Randomized Complete Block Design (RCBD) with three (3) replications. The field was divided into three blocks (replication). Each block was divided into five experimental units. The size of each experimental unit was $6 \mathrm{~m} \times 4 \mathrm{~m}$. The treatments were assigned in each block at random. Four fungicides were used as treatment with one control (Table. 1). Before sowing of lentil seeds furrows were made with power tiller. $20 \mathrm{~cm}$ distance was maintained between the furrows. The required amounts of seeds for each sub plot were taken in polyethylene bags and seeds are broadcasted at a rate of 40 $\mathrm{kg} / \mathrm{ha}$ in the furrows immediately. The furrows were covered with soil soon after sowing. Spray solution of each fungicide was prepared respectively in non-metal containers. Spraying was done with the help of a knapsack sprayer. Three liters of spray solution was sprayed in each experiment unit. Spraying was started at 20 days after sowing (DAS) and continued for one month at 7,10 and 15 days interval. Intercultural operation was done in order to maintain the normal hygienic condition of crop growth. Weeding was performed two times during the growing period of the crop. One weeding was done at 20 days and another at 35 days after sowing. Light irrigation was given after each weeding. Excess water was drained out immediately to save the crop from stagnant water. There were 5 treatments. The treatments are as follows:

$\mathrm{T}_{1}=$ Rovral $50 \mathrm{wp}(0.2 \%)$ (Iprodion)

$\mathrm{T}_{2}=$ Sceure $600 \mathrm{wg}(0.2 \%)$ (Fenamidone + Mancozeb)

$\mathrm{T}_{3}=$ Bavistin $70 \mathrm{wp}(0.2 \%)$ (Carbendazim)

$\mathrm{T}_{4}=$ Captan $50 \mathrm{wp}(0.2 \%)$ and

$\mathrm{T}_{5}=$ Control.

\section{Observation, Data Collection and Analysis}

The incidence of foot and root rot of lentil was recorded at 10 days interval. The incidence of the disease of lentil was calculated by the following formula:

Incidence $(\%)=\frac{\text { Number of infected plants }}{\text { Total number of plants }} \times 100$

The crop was harvested at fully matured stage. The crop of this field was harvested on 06, March 2012. Five plants from each plot were selected randomly for data collection on Growth parameter. The collected data were analyzed statistically. Analysis of Variance and LSD test were done to find out the significant difference among the treatment means [11].

\section{Results}

Incidence of foot and root rot of lentil due to application of fungicides at seven days interval

It is indicated in Table 1 that all the treatments had effect over the control in reducing the disease. Among the treatments, $\mathrm{T}_{2}$ (Secure $600 \mathrm{wg}$ ) was found most effective followed by $\mathrm{T}_{4}$ (Captan $50 \mathrm{wp}$ ) and $\mathrm{T}_{1}$ (Rovral $50 \mathrm{wp}$ ) and differed significantly from the other fungicides tested.

Table 1. Incidence of foot and root rot of lentil due to application of fungicides at seven days interval

\begin{tabular}{|c|c|c|c|c|c|}
\hline \multirow{2}{*}{ Treatment } & \multicolumn{5}{|c|}{ Disease incidence (\%) } \\
\cline { 2 - 6 } & $\begin{array}{c}25 \\
\text { DAS }\end{array}$ & $\begin{array}{c}35 \\
\text { DAS }\end{array}$ & $\begin{array}{c}45 \\
\text { DAS }\end{array}$ & $\begin{array}{c}55 \\
\text { DAS }\end{array}$ & Mean \\
\hline $\mathrm{T}_{1}$ & $1.48 \mathrm{ab}$ & $4.36 \mathrm{c}$ & $6.28 \mathrm{~b}$ & $7.07 \mathrm{c}$ & $4.80 \mathrm{c}$ \\
\hline $\mathrm{T}_{2}$ & $0.99 \mathrm{~d}$ & $1.99 \mathrm{e}$ & $3.66 \mathrm{~d}$ & $5.49 \mathrm{~d}$ & $3.03 \mathrm{e}$ \\
\hline $\mathrm{T}_{3}$ & $1.39 \mathrm{c}$ & $5.05 \mathrm{~b}$ & $7.96 \mathrm{a}$ & $\begin{array}{c}11.18 \\
\mathrm{~b}\end{array}$ & $6.40 \mathrm{~b}$ \\
\hline $\mathrm{T}_{4}$ & $1.51 \mathrm{ab}$ & $3.35 \mathrm{~d}$ & $5.03 \mathrm{c}$ & $6.96 \mathrm{c}$ & $4.21 \mathrm{~d}$ \\
\hline $\mathrm{T}_{5}$ & $1.67 \mathrm{a}$ & $6.82 \mathrm{a}$ & $8.21 \mathrm{a}$ & $\begin{array}{c}13 . \\
30 \mathrm{a}\end{array}$ & $7.50 \mathrm{a}$ \\
\hline $\mathrm{LSD}_{0.05}$ & 0.19 & 0.55 & 1.01 & 0.530 & 0.57 \\
\hline $\mathrm{CV}_{0}$ & 7.77 & 8.28 & 9.57 & 3.70 & 7.33 \\
\hline
\end{tabular}

$\mathrm{T}_{1}=$ Rovral $50 \mathrm{wp} ; \mathrm{T}_{2}=$ Secure $600 \mathrm{wg} ; \mathrm{T}_{3}=$ Bavistin $70 \mathrm{wp} ; \mathrm{T}_{4}=$ Captan 50 wp; $\mathrm{T}_{5}=$ Control

Figures in the column having common letter(s) do not differ significantly at $5 \%$ levels by LSD

\section{Incidence of Foot and Root Rot of Lentil Due to Spray at 10 Days Intervals}

Incidence of foot and root rot of lentil due to spray at 10 days intervals are shown in Table 2 . The incidence was minimum in $\mathrm{T}_{2}$ (Secure $600 \mathrm{wg}$ ) followed by $\mathrm{T}_{3}$ (Bavistin 70 $\mathrm{wp})$ and $\mathrm{T}_{1}($ Rovral $50 \mathrm{wp})$. Here, $\mathrm{T}_{3}$ and $\mathrm{T}_{1}$ were statistically similar.

Table 2. Incidence of foot and root rot of lentil due to application of fungicides at 10 days interval

\begin{tabular}{|c|c|c|c|c|c|}
\hline \multirow{2}{*}{ Treatment } & \multicolumn{5}{|c|}{ Disease incidence(\%) } \\
\cline { 2 - 6 } & 25 DAS & $\begin{array}{c}35 \\
\text { DAS }\end{array}$ & $\begin{array}{c}45 \\
\text { DAS }\end{array}$ & $\begin{array}{c}55 \\
\text { DAS }\end{array}$ & Mean \\
\hline $\mathrm{T}_{1}$ & $4.64 \mathrm{a}$ & $7.38 \mathrm{~b}$ & $8.75 \mathrm{bc}$ & $10.66 \mathrm{c}$ & $7.86 \mathrm{~b}$ \\
\hline $\mathrm{T}_{2}$ & $3.00 \mathrm{~d}$ & $5.49 \mathrm{~d}$ & $7.76 \mathrm{~d}$ & $9.84 \mathrm{c}$ & $6.52 \mathrm{c}$ \\
\hline $\mathrm{T}_{3}$ & $4.22 \mathrm{~b}$ & $6.43 \mathrm{c}$ & $8.12 \mathrm{~cd}$ & $11.49 \mathrm{~b}$ & $7.57 \mathrm{~b}$ \\
\hline $\mathrm{T}_{4}$ & $4.72 \mathrm{a}$ & $8.37 \mathrm{a}$ & $10.73 \mathrm{a}$ & $12.55 \mathrm{a}$ & $9.09 \mathrm{a}$ \\
\hline $\mathrm{T}_{5}$ & $4.90 \mathrm{c}$ & $8.56 \mathrm{c}$ & $11.51 \mathrm{~b}$ & $12.96 \mathrm{a}$ & $9.48 \mathrm{a}$ \\
\hline $\mathrm{LSD}_{0.05}$ & 0.39 & 0.59 & 0.91 & 1.29 & 0.78 \\
\hline $\mathrm{CV}_{0}$ & 5.38 & 4.72 & 5.59 & 6.24 & 5.48 \\
\hline
\end{tabular}

$\mathrm{T}_{1}=$ Rovral $50 \mathrm{wp} ; \mathrm{T}_{2}=$ Secure $600 \mathrm{wg} ; \mathrm{T}_{3}=$ Bavistin $70 \mathrm{wp} ; \mathrm{T}_{4}=$ Captan 50 wp; $\mathrm{T}_{5}=$ Control

Figures in the column having common letter(s) do not differ significantly at $5 \%$ levels by LSD.

\section{Incidence of Foot and Root Rot of Lentil Due to Fungicides Spray at 15 Days Interval}

Data on the incidence of foot and root rot of lentil due to fungicides spray at 15 days interval are presented in Table 3. Among the treatments, $T_{2}$ (Secure $600 \mathrm{wg}$ ) was found most 
effective followed by $\mathrm{T}_{1}$ (Rovral 50wp) and differed significantly from the other fungicides tested. $\mathrm{T}_{3}$ and $\mathrm{T}_{4}$ had no significant on reduction of foot and root disease. $\mathrm{T}_{2}$ (Secure $600 \mathrm{wg}$ ) showed 3.53\% incidence of foot and root rot disease whereas, $\mathrm{T}_{5}$ showed

Table 3. Incidence of foot and root rot of lentil due to application of fungicides at 15 days interval

\begin{tabular}{|c|c|c|c|c|c|}
\hline \multirow{2}{*}{ Treatment } & \multicolumn{5}{|c|}{ Disease incidence(\%) } \\
\cline { 2 - 6 } & $\begin{array}{c}25 \\
\text { DAS }\end{array}$ & $\begin{array}{c}35 \\
\text { DAS }\end{array}$ & $\begin{array}{c}45 \\
\text { DAS }\end{array}$ & 55 DAS & Mean \\
\hline $\mathrm{T}_{1}$ & $1.68 \mathrm{c}$ & $3.37 \mathrm{c}$ & $5.14 \mathrm{ab}$ & $6.64 \mathrm{~b}$ & $4.21 \mathrm{~b}$ \\
\hline $\mathrm{T}_{2}$ & $1.34 \mathrm{~d}$ & $2.75 \mathrm{c}$ & $4.30 \mathrm{~b}$ & $5.74 \mathrm{c}$ & $3.53 \mathrm{c}$ \\
\hline $\mathrm{T}_{3}$ & $2.12 \mathrm{~b}$ & $4.97 \mathrm{a}$ & $6.18 \mathrm{a}$ & $9.39 \mathrm{a}$ & $5.67 \mathrm{a}$ \\
\hline $\mathrm{T}_{4}$ & $2.26 \mathrm{~b}$ & $4.42 \mathrm{a}$ & $6.12 \mathrm{a}$ & $9.31 \mathrm{a}$ & $5.53 \mathrm{a}$ \\
\hline $\mathrm{T}_{5}$ & $2.85 \mathrm{a}$ & $4.99 \mathrm{a}$ & $6.40 \mathrm{a}$ & $9.75 \mathrm{a}$ & $5.99 \mathrm{a}$ \\
\hline $\mathrm{LSD}_{0.05}$ & 0.30 & 0.71 & 1.29 & 0.55 & 0.71 \\
\hline $\mathrm{CV}_{0}$ & 9.02 & 10.05 & 12.82 & 3.66 & 8.89 \\
\hline
\end{tabular}

$\mathrm{T}_{1}=$ Rovral $50 \mathrm{wp} ; \mathrm{T}_{2}=$ Secure $600 \mathrm{wg} ; \mathrm{T}_{3}=$ Bavistin $70 \mathrm{wp} ; \mathrm{T}_{4}=$ Captan 50 wp; $\mathrm{T}_{5}=$ Control

Figures in the column having common letter(s) do not differ significantly at $5 \%$ levels by LSD

The plants infected with foot and root rot showed brownish at the leaves and stem (Fgiure1). The roots become rotten. The infected root did not have hairs due to damage by the pathogen (Fgiure2).

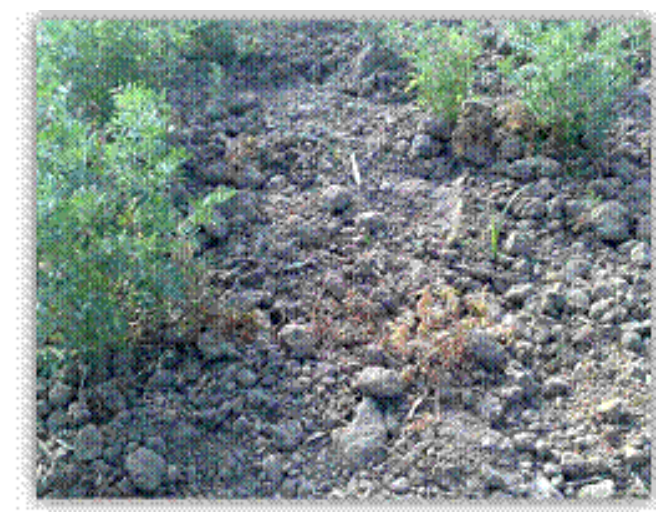

Fgiure1. Plant showing food and root rot symptoms in the field

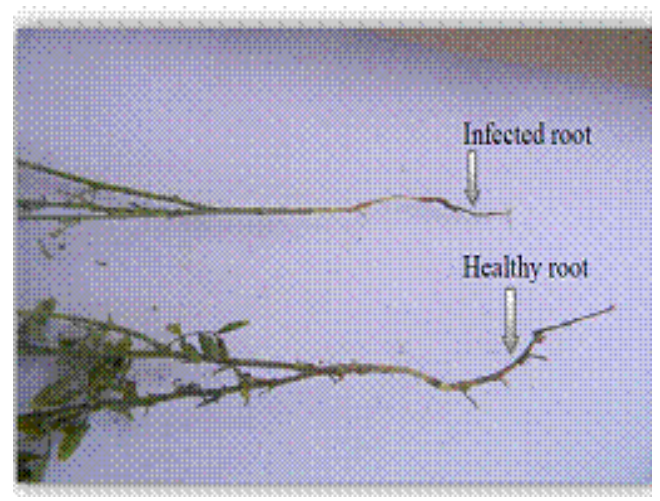

Fgiure2. Infected root showing foot and root rot symptoms

\section{Effects of Some Fungicides in Relation to Yield and Yield Related Characters of Lentil Due to Weekly Spray of Fungicides}

Data of grain yield and yield related characters of lentil due to weekly spray of fungicides are shown in Table 4. Highest mean plant height was obtained in $T_{2}$ (Secure $600 \mathrm{wg}$ ), whereas $\mathrm{T}_{5}$ (control) showed the lowest plants height $(26.80 \mathrm{~cm})$. But $\mathrm{T}_{2}$ is statistically similar in increasing plant height with T4 and T1.

$\mathrm{T}_{2}$ showed highest number of pods per plant (42.27) followed by $\mathrm{T}_{1}$ and $\mathrm{T} 4$. But effect of $\mathrm{T}_{2}$ and $\mathrm{T}_{1}$ on pods/plant were statistically similar. Other hand T2 showed highest positive effect on 100 seed weight ( $1.79 \mathrm{gm})$ and yield per ha $(1135.33 \mathrm{~kg})$.

Table 4. Grain yield of lentil due to application of fungicides at 7 days interval

\begin{tabular}{|c|c|c|c|c|}
\hline Treatment & $\begin{array}{c}\text { Plants } \\
\text { Height } \\
\text { (Mean) } \\
\text { cm }\end{array}$ & Pods/Plant(Mean) & $\begin{array}{c}100 \\
\text { seed } \\
\text { weight } \\
(\mathrm{gm})\end{array}$ & $\begin{array}{c}\text { Yield } \\
(\mathrm{kg}) / \\
\text { ha }\end{array}$ \\
\hline $\mathrm{T}_{1}$ & $28.33 \mathrm{ab}$ & $40.07 \mathrm{a}$ & $1.73 \mathrm{ab}$ & $976.67 \mathrm{~b}$ \\
\hline $\mathrm{T}_{2}$ & $30.07 \mathrm{a}$ & $42.27 \mathrm{a}$ & $1.79 \mathrm{a}$ & $1135.33 \mathrm{a}$ \\
\hline $\mathrm{T}_{3}$ & $26.93 \mathrm{~b}$ & $28.53 \mathrm{c}$ & $1.76 \mathrm{a}$ & $933.00 \mathrm{bc}$ \\
\hline $\mathrm{T}_{4}$ & $29.87 \mathrm{a}$ & $36.73 \mathrm{~b}$ & $1.74 \mathrm{ab}$ & $892.00 \mathrm{c}$ \\
\hline $\mathrm{T}_{5}$ & $26.80 \mathrm{~b}$ & $28.47 \mathrm{c}$ & $1.68 \mathrm{~b}$ & $680.00 \mathrm{~d}$ \\
\hline $\mathrm{LSD}_{0.05}$ & 2.36 & 2.53 & 0.06 & 58.84 \\
\hline $\mathrm{CV}_{0}$ & 4.5 & 4 & 1.6 & 3.5 \\
\hline
\end{tabular}

$\mathrm{T}_{1}=$ Rovral $50 \mathrm{wp} ; \mathrm{T}_{2}=$ Secure $600 \mathrm{wg} ; \mathrm{T}_{3}=$ Bavistin $70 \mathrm{wp} ; \mathrm{T}_{4}=$ Captan 50 wp; $\mathrm{T}_{5}=$ Control

Figures in the column having common letter(s) do not differ significantly at $5 \%$ levels by LSD

\section{Effects of Some Fungicides in Relation to Yield And Yield Related Characters of Lentil Due to 10 Days Interval Spray of Fungicides}

Table 5. Grain yield of lentil due to application of fungicides at 10 days interval

\begin{tabular}{|c|c|c|c|c|}
\hline Treatments & $\begin{array}{c}\text { Plants Height } \\
\text { (Mean) cm }\end{array}$ & $\begin{array}{c}\text { Pods/ } \\
\text { Plant } \\
\text { (Mean) }\end{array}$ & $\begin{array}{c}100 \text { seed } \\
\text { weight } \\
(\mathrm{gm})\end{array}$ & $\begin{array}{c}\text { Yield } \\
(\mathrm{kg}) / \\
\text { ha }\end{array}$ \\
\hline $\mathrm{T}_{1}$ & $26.27 \mathrm{~b}$ & $32.40 \mathrm{c}$ & $1.81 \mathrm{~b}$ & $828.00 \mathrm{c}$ \\
\hline $\mathrm{T}_{2}$ & $29.13 \mathrm{a}$ & $36.67 \mathrm{a}$ & $1.99 \mathrm{a}$ & $1019.67 \mathrm{a}$ \\
\hline $\mathrm{T}_{3}$ & $26.40 \mathrm{~b}$ & $33.47 \mathrm{bc}$ & $1.79 \mathrm{~b}$ & $905.33 \mathrm{~b}$ \\
\hline $\mathrm{T}_{4}$ & $28.53 \mathrm{a}$ & $36.47 \mathrm{ab}$ & $1.85 \mathrm{~b}$ & $1005.33 \mathrm{a}$ \\
\hline $\mathrm{T}_{5}$ & $\begin{array}{c}25.73 \\
\mathrm{~b}\end{array}$ & $31.07 \mathrm{c}$ & $1.81 \mathrm{~b}$ & $815.00 \mathrm{c}$ \\
\hline $\mathrm{LSD} 0.05$ & 2.05 & 3.02 & 0.12 & 47.58 \\
\hline $\mathrm{CV} \%$ & 4.14 & 4.89 & 3.24 & 2.86 \\
\hline
\end{tabular}

$\mathrm{T}_{1}=$ Rovral $50 \mathrm{wp} ; \mathrm{T}_{2}=$ Secure $600 \mathrm{wg} ; \mathrm{T}_{3}=$ Bavistin $70 \mathrm{wp} ; \mathrm{T}_{4}=$ Captan 50 wp; $\mathrm{T}_{5}=$ Control

Figures in the column having common letter(s) do not differ significantly at $5 \%$ levels by LSD 
$\mathrm{T}_{2}$ showed profound effect on grain yield and yield related characters of lentil due to fungicides spray at 10 days interval (Table 5). Plants height (mean) was $25.73 \mathrm{~cm}$ in $\mathrm{T}_{5}$ as compared to $26.27 \mathrm{~cm}$ in T1. Maximum plant height was $29.13 \mathrm{~cm}$ obtained in $T_{2}$. Pods/plant was highest in $T_{2}$, whereas minimum no of pods/plant was 31.07 in $T_{5} . T_{3}$ showed significant yield $(905.33 \mathrm{~kg} / \mathrm{ha})$, but best yield was obtained $1019.67 \mathrm{~kg} / \mathrm{ha}$ in $\mathrm{T}_{2} . \mathrm{T}_{5}$ showed the minimum yield per hector $(815.00 \mathrm{~kg} / \mathrm{ha})$.

\section{Effects of Some Fungicides in Relation to Yield Contributing Characters and Yield Of Lentil Due to Fungicides Spray a 15 Days Interval}

Effects of some fungicides in relation to yield contributing characters and of lentil due to fungicides spray at 15 days interval are presented in Table 6 . In mean plants height, $T_{1}$ showed significant result $(29.93 \mathrm{~cm})$ in comparison with $29.67 \mathrm{~cm}$ in $\mathrm{T}_{4}$ and minimum $28.87 \mathrm{~cm}$ in $\mathrm{T}_{5}$. Maximum plants height was $32.80 \mathrm{~cm}$ in $T_{2}$. Maximum no of pods/plant was 39.93 in $T_{2}$ as compared to 39.07 in $T_{3}$. They were statistically insignificant. $\mathrm{T}_{2}$ showed the significant result $(1.81 \mathrm{gm})$ of 100 seeds weight as compared to $1.75 \mathrm{gm}$ in both $\mathrm{T}_{4}$ and $\mathrm{T}_{5}$. Maximum yield per ha is $1043.33 \mathrm{~kg} / \mathrm{ha}$ in $\mathrm{T}_{2}$ and insignificant to $772.67 \mathrm{~kg} /$ hector in $\mathrm{T}_{5} . \mathrm{T}_{1}$ had 873.33 $\mathrm{kg} / \mathrm{ha}$ in $\mathrm{T}_{1}$ is significant to $855.33 \mathrm{~kg} / \mathrm{ha}$ in $\mathrm{T}_{3} . \mathrm{T}_{4}$ showed statistically insignificant result $(994.33 \mathrm{~kg} / \mathrm{ha})$

Table 6. Grain yield of lentil due to application of fungicides at 15 days interval

\begin{tabular}{|c|c|c|c|c|}
\hline Treatments & $\begin{array}{c}\text { Plants } \\
\text { height } \\
(\text { Mean }) \mathrm{cm}\end{array}$ & $\begin{array}{c}\text { Pods/pl } \\
\text { ant } \\
(\text { Mean })\end{array}$ & $\begin{array}{c}100 \text { seed } \\
\text { weight } \\
(\mathrm{gm})\end{array}$ & $\begin{array}{c}\text { Yield (kg)/ } \\
\text { ha }\end{array}$ \\
\hline $\mathrm{T}_{1}$ & $29.93 \mathrm{~b}$ & $35.47 \mathrm{~b}$ & $1.77 \mathrm{ab}$ & $873.33 \mathrm{c}$ \\
\hline $\mathrm{T}_{2}$ & $32.80 \mathrm{a}$ & $39.93 \mathrm{a}$ & $1.81 \mathrm{a}$ & $1043.33 \mathrm{a}$ \\
\hline $\mathrm{T}_{3}$ & $31.87 \mathrm{a}$ & $39.07 \mathrm{a}$ & $1.76 \mathrm{abc}$ & $855.33 \mathrm{c}$ \\
\hline $\mathrm{T}_{4}$ & $29.67 \mathrm{~b}$ & $33.10 \mathrm{c}$ & $1.72 \mathrm{abc}$ & $994.33 \mathrm{~b}$ \\
\hline $\mathrm{T}_{5}$ & $28.87 \mathrm{~b}$ & $32.33 \mathrm{c}$ & $1.69 \mathrm{c}$ & $772.67 \mathrm{~d}$ \\
\hline $\mathrm{LSD}_{0.05}$ & 1.71 & 1.41 & 0.06 & 41.32 \\
\hline $\mathrm{CV}_{0}$ & 3.08 & 2.16 & 1.29 & 2.50 \\
\hline
\end{tabular}

$\mathrm{T}_{1}=$ Rovral $50 \mathrm{wp} ; \mathrm{T}_{2}=$ Secure $600 \mathrm{wg} ; \mathrm{T}_{3}=$ Bavistin $70 \mathrm{wp} ; \mathrm{T}_{4}=$ Captan 50 wp; $\mathrm{T}_{5}=$ Control

Figures in the column having common letter(s) do not differ significantly at $5 \%$ levels by LSD

\section{Discussion}

It is quite evident that foot and root rot of lentil is caused by Fusarium oxysporum and Sclerotium rolfsii [6] and have immense impact on germination, disease incidence, seedling mortality and yield. The experiment was conducted to asses' foliar application of fungicides on lentil production and to select a fungicide for controlling foot and root rot of lentil. From the result it was observed that all the fungicides have enormous effect on reducing disease incidence of lentil. All the fungicides significantly reduce disease incidence of lentil. Among the treatments, secure $600 \mathrm{wg}$ gave lower percentage of disease incidence. Secure $600 \mathrm{wg}$ showed $3.03 \%, 6.52 \%$, $3.53 \%$ disease incidence due to weekly spray, spray at 10 days interval and at 15 days interval respectively. Control showed $13.30 \%, 12.96 \%$, and $9.75 \%$ at the respective plots. Efficacy of fungicides was tested and Secure 600 WG was found to show the lowest disease severity followed by Rovral-50 WP in controlling foot and root rot of lentil [2]

Mean plants height was $30.07 \mathrm{~cm}$ at Secure $600 \mathrm{wg}$ applied plots while control showed the lower plants height $(26.80 \mathrm{~cm})$ at weekly spray. Mean pods per plant was highest (42.27) at secure $600 \mathrm{wg}$ weekly spray. Secure $600 \mathrm{wg}$ showed the highest $(1135.33 \mathrm{~kg} / \mathrm{ha}$.) yield against 680.00 $\mathrm{kg} / \mathrm{ha}$. in control plots at weekly spray. In respect of spray at 10 days interval plots, Secure $600 \mathrm{wg}$ showed $1019.67 \mathrm{~kg} / \mathrm{ha}$ while control plots gave $815.00 \mathrm{~kg} / \mathrm{ha}$. yield of lentil grain. While spray was at 15 days interval yield $(\mathrm{kg} / \mathrm{ha}$.) ranged from 1043.33 to $772.67 \mathrm{~kg} / \mathrm{ha}$. Secure $600 \mathrm{wg}$ plots showed significantly higher yield of $1043.33 \mathrm{~kg} / \mathrm{ha}$.

The result of the present study clearly indicates that, spraying the fungicides in this experiment which promotes yield promoting characters and increased yield and thus considerably reduced foot rot diseases. However, findings of this study suggested for extensive further study in this discipline.

\section{REFERENCES}

[1] Anonymous. 1986. Annual report 1985-86. Plant Path. Div. BARI, Gazipur. 19pp.

[2] Anonymous. 2011 Annual report 2010-2011. Plant Path. Div. BARI, Gazipur

[3] Aycock, R. 1966. Stem rot and other diseases caused by $S$. rolfsii. Tech. Bull. No. 174. Agric. Expt. Station, North Carolina State University, Raleigh. 202pp.

[4] BARI Hand book, 2005, Dal fasol utpadon podoti. Page. 101-104.

[5] BBS. 2011. Bangladesh Bureau of Statistics. Ministry of Planning. Dhaka, Bangladesh. 126.

[6] Dey, T.K., Ali, M.S. and Chowdhury, N. 1993. Vegetative growth and sporangia production in Phytopthora colocaseae. Indian J. Root crops 17 (2): 142-146.

[7] Haque, A.H.M.M., 2010. Annual Progress Report "Quality improvement of farmer's stored seeds of Mungbean, lentil and chickpea and its relation to disease development in Bangladesh" presented in Annual Workshop on held on 24-25 May, 2010 organized by Krishi Goveeshona Foundation (KGF), BARC, Khamarbari, Dhaka.

[8] Khare, M. V.; Agrawal. S. C. and Jain, A. C. 1979. Diseases of lentil and their control. Technical bulletin. Jabalpur, Madhya Pradwsh, India: Jawaharlal Nehru Krisi Viswa Vidyalaya. 
[9] Sattar, M.A., Podder, A.R., Chandra, M.C., and Rahman, M. 1996. The most promising BNF technology for green legume production in Bangladesh. BNF Association, Dhaka, BD. 28, Nov, 1994pp. 15-20.

[10] Singh, J. and Tripathy, S. C. 1999. Mycoflora association with stored seeds of Lens esculenta. Herbal Pesticide Lab., Dept. of Botany, Gorakhpur Univ. Gorakhpur, India.

[11] Zaman, S. M. H., K. Rahim and M. Howladar. 1982. Simple lessons from biometry. Bangladesh Rice Research Institute, Joydebpur, Gazipur. Publication No. 54. 